\title{
PERSEPSI PETANI TERHADAP PENERAPAN BUDIDAYA PADI DENGAN METODE SYSTEM OF RICE INTENSIFICATION (SRI) DI KECAMATAN INDRAPURI KABUPATEN ACEH BESAR PROVINSI ACEH
}

\author{
Mujiburrahmad*, Irwan, Muhammad Reza Fahlevy \\ Program Studi Agribisnis, Fakultas Pertanian, Universitas Syiah Kuala \\ Jl. Tgk. Hasan Krueng Kalee No. 3, Kopelma Darussalam, Banda Aceh, Aceh \\ *Corresponding author: mujiburrahmad@unsyiah.ac.id
}

\begin{abstract}
In order to encourage the stability of rice production, the government set a policy to implement integrated factory management (GP-PTT) and other rice intensification action included application which System of Rice Intensification (SRI). The purpose of this study is to determine farmers' perceptions of the application of SRI cultivation methods, and to determine the relationship between farmer characteristics and perceptions of the application of the SRI method. The study was conducted from October to December 2018. The study located at Gampong Cot Kareung, Indrapuri subdistrict, Aceh Besar district, Aceh Province. There were 30 members of Tani Bijeh Mata Women's Group were targeted as research respondents. The basic analytics is descriptive method and the data analyzed by spearman rank correlation. The results of this study as a whole the average perceptions of farmers members of KWT Bijeh Mata conducted have a value of 3.3 by using the Likert measurement scale indicating that the level of perception is still categorized as good. There is a relationship between age characteristics and farmers' perceptions and there is a strong relationship to the characteristics of ownership status with perception. As for income characteristics, land area, education, experience and intensity of participating in agricultural training did not have a relationship with farmers' perceptions of the SRI cultivation method.
\end{abstract}

Keywords: cultivation method, rice, SRI, perception, farmers

\begin{abstract}
Abstrak: Untuk mendukung stabilitas produksi beras, pemerintah menetapkan kebijakan untuk menerapkan manajemen pabrik terpadu (GP-PTT) dan gerakan intensifikasi padi lainnya yang mencakup pengembangan System of Rice Intensification (SRI). Tujuan dari penelitian ini adalah untuk mengetahui persepsi petani terhadap penerapan metode budidaya SRI, dan untuk mengetahui hubungan antara karakteristik petani dengan persepsi terhadap penerapan metode SRI. Penelitian dilakukan pada bulan Oktober sampai Desember 2018. Lokasi penelitian dilakukan di Gampong Cot Kareung, Kecamatan Indrapuri, Kabupaten Aceh Besar, Provinsi Aceh. Populasi dalam penelitian ini yang dituju adalah petani yang berada di Kelompok Wanita Tani Bijeh Mata yang beranggotakan sebanyak 30 orang. Metode analisis yang digunakan yaitu metode deskriptif dan korelasi rank spearman. Hasil penelitian ini secara keseluruhan rata rata persepsi petani anggota KWT Bijeh Mata dilakukan memiliki nilai 3,3 dengan menggunakan skala pengukuran likert menunjukkan bahwa tingkat persepsi masih dikategorikan baik. Adanya hubungan antara karekteristik umur dengan persepsi petani serta terdapat hubungan yang cukup kuat pada status kepemilikan dengan persepsi. Untuk karakteristik pendapatan, luas lahan, pendidikan, pengalaman serta intensitas mengikuti pelatihan pertanian tidak memiliki hubungan dengan persepsi petani terhadap metode budidaya SRI.
\end{abstract}

Kata kunci: metode budidaya, padi, SRI, persepsi, petani 


\section{PENDAHULUAN}

Indonesia dikenal sebagai negara agraris yang menandakan bahwa mayoritas dari penduduk Indonesia bermata pencaharian di bidang pertanian, hal ini didukung oleh kondisi alam di Indonesia yang memiliki iklim tropis, yang mana iklim tersebut sangat berpotensial di bidang pertanian. Hingga sekarang perekonomian negara Indonesia masih sangat bergantung pada sektor pertanian. Pembangunan pertanian sejak repelita I pada tahun 1969 sampai dengan sekarang masih menjadi perioritas utama dengan berbagai program seperti ekstensifikasi, intensifikasi dan peremajaan untuk meningkatkan produktivitas pertanian, pendapatan petani dan pendapatan nasional (Tuwo, 2011).

Seiring dengan pertumbuhan penduduk menurut BPS dari tahun 1971 sampai 2016 yang terus meningkat rata rata sebesar $1,726 \%$ setiap tahunnya membuat permintaan akan komoditi beras ini semakin meningkat. Akan tetapi kondisi ini tidak disertai dengan jumlah lahan pertanian yang menjadi penyedia komoditi beras terus menerus berkurang setiap tahunnya yang diakibatkan oleh alih fungsi lahan pertanian menjadi lahan non pertanian seperti kebutuhan lahan perumahan, industri dan lain lain. Dalam kondisi ini dibutuhkan teknologi dan inovasi dalam meningkatkan produksi pertanian untuk dapat terus memenuhi permintaan yang terus menerus mengalami kenaikan setiap tahunnya.

Menangani hal ini pemerintah mecanangkan sebuah kebijakan untuk melaksanakan Gerakan Penerapan Pengelolaan Tanaman Terpadu (GP-PTT) dan intensifikasi padi lainnya secara nasional. Salah satu diantaranya adalah pengembangan System of Rice Intensification (SRI). Metode ini merupakan teknologi yang diaplikasikan dalam upaya intensifikasi tanaman yang bertujuan untuk meningkatkan hasil produksi padi pada suatu lahan serta mengatur penggunaan input kimia dan penggunaan air yang dapat mempertahankan keragaman akan mikroba yang tersedia pada lahan yang berbasis pertanian organik yang berkelanjutan.

Penggunaan metode System of Rice Intensification (SRI) memiliki beberapa perbedaan yang mendasar khas yang membedakannya dengan metode konvensional yaitu pada (a) lama menyemaian benih yang lebih cepat, (b) mengatur penggunaan air yang lebih efesien, (c) mengefesiensikan penggunaan saprodi dan penggunaan air, (d) memperbaiki kualitas tanah sawah, (e) mengembangkan usaha padi sawah yang ramah lingkungan, di harapkan dapat meningkatkan hasil dan memberikan nilai lebih yang akan meningkatkan pendapatan dan kesejahteraan petani dan masyarakat. Berdasarkan Tabel 1 dapat dilihat beberapa perbedaan yang memperlihatkan kelebihan pada metode SRI dari pada metode tanam konvensional seperti input benih yang lebih kecil, terdapatnya penyeleksian benih, kebutuhan air yang lebih sedikit sampai rendemen gabah yang lebih tinggi dari pada metode konvensional serta lebih ramah lingkungan.

Tabel 1. Perbedaan Metode SRI Dibandingkan dengan Metode Konvensional

\begin{tabular}{|c|c|c|c|}
\hline No. & Komponen & Konvensional & SRI \\
\hline 1. & Kebutuhan benih & $30-40 \mathrm{~kg} / \mathrm{ha}$ & $5-7 \mathrm{~kg} / \mathrm{ha}$ \\
\hline 2. & Pengujian benih & Tidak dilakukan & Dilakukan pengujian \\
\hline 3. & Umur pesemaian & 20-30 HHS & 7-10HHS \\
\hline 4. & Pengolahan lahan & 2-3 kali (struktur lumpur) & $\begin{array}{l}4 \text { kali (struktur lumpur dan } \\
\text { rata) }\end{array}$ \\
\hline 5. & Jumlah tanaman per lubang & Rata-rata 5 bibit / lubang & $1 \mathrm{bibit} / \mathrm{lubang}$ \\
\hline 6. & Kebutuhan air irigasi & 0,61 liter/detik & 0,42 liter/detik \\
\hline 7. & Posisi akar waktu tanam & Tidak teratur & Posisi akar horizontal (L) \\
\hline 8. & Pengairan & Terus di ganangi & Disesuaikan dengan kebutuhan \\
\hline 9. & Pemupukan & Mengutamakan pupuk kimia & $\begin{array}{l}\text { Hanya menggunakan pupuk } \\
\text { organik }\end{array}$ \\
\hline 10. & Penyiangan & $\begin{array}{l}\text { Diarahkan } \\
\text { gulma }\end{array}$ & $\begin{array}{l}\text { Diarahkan dengan pengelolaan } \\
\text { perakaran }\end{array}$ \\
\hline 11. & Rendemen Gabah & $50-60 \%$ & $60-70 \%$ \\
\hline
\end{tabular}

Sumber: Kurniadiningsih dan Legowo, 2012 
Tabel 2. Luas Tanam, Luas Panen dan Produksi Padi Sawah Menurut Kecamatan di Kabupaten Aceh Besar,

\begin{tabular}{|c|c|c|c|c|}
\hline No & Kecamatan & Luas Tanam (Ha) & Luas Panen (Ha) & Produksi (Ton) \\
\hline 1. & Lhoong & 1.780 & 1.753 & 11.850 \\
\hline 2. & Lhoknga & 1.433 & 1.471 & 9.473 \\
\hline 3. & Leupung & 550 & 435 & 20.49 \\
\hline 4. & Indrapuri & 4.897 & 4.759 & 33.123 \\
\hline 5. & Kuta Cot Gile & 3.543 & 3.915 & 25.878 \\
\hline 6. & Seulimeum & 5.696 & 4.977 & 32.201 \\
\hline 7. & Kota Jatoh & 1.705 & 1.940 & 9.933 \\
\hline 8. & Lambah Seulawah & 1.526 & 1.026 & 6.392 \\
\hline 9. & Mesjid Raya & 50 & 25 & 120 \\
\hline 10. & Darussalam & 1.415 & 1.076 & 6.348 \\
\hline 11. & Baitussalam & 168 & 148 & 981 \\
\hline 12. & Kuta Baro & 2.604 & 2.442 & 14.041 \\
\hline 13. & Montasik & 3.268 & 3.268 & 19.673 \\
\hline 14. & Blang Bintang & 1.810 & 1.843 & 12.532 \\
\hline 15. & Ingin Jaya & 2.811 & 2.546 & 15.632 \\
\hline 16. & Kerueng Barona Jaya & 253 & 226 & 1.492 \\
\hline 17. & Suka Makmur & 3.294 & 3.294 & 19.105 \\
\hline 18. & Kuta Malaka & 1.357 & 1.264 & 8.115 \\
\hline 19. & Simpang Tiga & 2.398 & 2.397 & 15.461 \\
\hline 20. & Darul Imarah & 451 & 850 & 5.338 \\
\hline 21. & Darul Kamal & 681 & 681 & 4.033 \\
\hline 22. & Peukan Bada & 690 & 544 & 2.986 \\
\hline 23. & Pulo Aceh & 313 & 313 & 2.213 \\
\hline \multirow{3}{*}{\multicolumn{2}{|c|}{ Aceh Besar }} & 43.096 & 41.193 & 258.969 \\
\hline & & 49.892 & 47.277 & 310.477 \\
\hline & & 42.234 & 38.429 & 264.190 \\
\hline
\end{tabular}

Sumber : BPS Aceh Besar dalam angka, 2017

Salah satu lumbung padi penting yang berada di Kabupaten Aceh Besar adalah Kecamatan Indrapuri dimana daerah ini memiliki luas tanam padi sawah kedua terbesar dengan luas $4.897 \mathrm{Ha}$ setelah Kecamatan Seulimeum yang memiliki luas tanam sebesar $5.696 \mathrm{Ha}$, Kecamatan Indrapuri memiliki produksi padi sawah terbesar dengan angka mencapai 33.123 Ton yang memiliki sawah yang beririgasi baik membuat Indrapuri menjadi lokasi yang ideal menjadi tempat potensi metode SRI dilakukan. Luas panen dan produksi padi di Kabupaten Aceh Besar dapat dilihat pada Tabel 2.

Tahun 2015 pemerintah Kabupaten Aceh Besar melalui Dinas Pertanian telah melakukan bimbingan tentang pengaplikasian metode SRI melalui penyuluhan dan pemberian bantuan pupuk organik kepada delapan kecamatan berbeda yakni: Suka makmur, Blang Bintang, Kuta Malaka, Ingin Jaya, Krueng Barona Jaya, Darussalam, Montasik, Kuta Baro, Indrapuri dan Simpang Tiga. Pengaplikasian sebuah teknologi baru yang masuk dalam masyarakat yang akan menggantikan metode pembudidayaan konvensional yang selama ini mereka lakukan memerlukan waktu untuk dapat di adopsi masyarakat dimana perlunya bimbingan dan penyuluhan akan teknologi yang akan diterapkan. Kecamatan Indrapuri desa yang mendapatkan pengenalan dan bimbingan mengenai metode SRI dan berhasil menunjukkan keberhasilan yakni di Desa Cot Kareung akan tetapi setelah mendapat hasil yang memuaskan pada saat disuluhkan pada petani, kini dari hasil pengamatan yang dilakukan saat pra penelitian para petani di daerah tersebut masih kembali menggunakan metode budidaya konvensional yang sebelumnya mereka lakukan dengan alasan tidak sebandingnya pekerjaan yang bertambah dan harga yang di terima petani. Ditemukan selisih antara harapan dan fakta yang terjadi di lapangan yang membuat perlu dilakukan penelitian tentang "Persepsi Petani Terhadap Penerapan Budidaya Padi Dengan Metode SRI. 
Adapun tujuan dari penelitian ini adalah (1) Mengetahui persepsi petani terhadap penerapan metode budidaya SRI, dan (2) Mengetahui hubungan antara karakteristik petani dengan persepsi terhadap penerapan metode SRI.

\section{METODE PENELITIAN}

Penelitian ini dilakukan pada tahun 2018, di bulan Oktober sampai Desember 2018. Lokasi penelitian dilakukan di Desa Cot Kareung Kecamatan Indrapuri, Kabupaten Aceh Besar, Provinsi Aceh. Populasi dalam penelitian ini yang dituju adalah petani yang berada di Kelompok Wanita Tani Bijeh Mata yang beranggotakan sebanyak 30 orang petani di Kecamatan Indrapuri Kabupaten Aceh Besar, sebagai penerima manfaat penyuluhan dan kebun demplot percontohan metode budidaya SRI. Dikarenakan jumlah populasi yang menjadi objek penelitian hanya berjumlah 30 orang dan memiliki karakteristik yang hampir serupa dalam segi bertempat tinggal dan lahan yang berdekatan serta masuk ke dalam kelompok tani yang sama maka digunakanlah metode pengambilan sampel jenuh atau dengan nama lain sensus yang mengambil seluruh populasi digunakan sebagai sampel.

\section{Model Analisis}

Analisis deskriptif yang bertujuan untuk mendapatkan informasi dari karakteristik petani seperti umur, pendapatan, luas lahan, jenis kelamin, pendidikan, status kepemilikan lahan, media informasi, dan interaksi dengan petani lain. Penelitian ini ingin mengetahui hubungan karakteristik dengan persepsi petani terhadap penerapan metode SRI. Data primer yang terkumpul diolah dengan menggunakan rumus korelasi peringkat rank spearman dengan rumus korelasi peringkat Rank Spearman (Siegel, 1992) sebagai berikut :

$$
r_{s}=\frac{6 \sum \mathrm{d}_{\mathrm{i}}^{2}}{n\left(n^{2}-1\right)}
$$

Keterangan:

$\mathrm{d}$ : Selisih dua jenjang untuk indikator yang sama

$\mathrm{n}$ : Banyak jenjang

rs : Koefesien korelasi rank spearman

\section{HASIL DAN PEMBAHASAN}

\section{Karakteristik Petani}

Umur merupakan usia dari responden yang dinyatakan dalam tahun. Menurut BPS umur digolongkan kepada 3 bagian yakni umur belum produktif yakni dari $0-15$ tahun kemudian umur produktif $15-64$ tahun dan umur tidak produktif $>64$ tahun dimana petani yang termasuk ke dalam golongan umur yang produktif cenderung dapat lebih mampu dan inovatif dalam menjalankan sebuah usaha pertanian, sedangkan petani yang lebih tua cenderung lebih lambat dan kaku dalam menjalankan usaha pertanian yang memerlukan kekuatan fisik yang prima dan keberanian untuk beradaptasi dengan teknologi yang terus berkembang dalam bidang pertanian. Didukung oleh Soekartawi (2005) makin muda usia biasanya petani mempunyai semangat dan rasa ingin tahu yang besar, sehingga mereka lebih cepat untuk melakukan adopsi inovasi. Dilihat pada Tabel 3 maka seluruh populasi petani yang tergabung dalam kelompok wanita tani Bijeh Mata seluruhnya masih tergolong kedalam usia produktif. Secara lengkap karakteristik petani responden dapat dilihat pada Tabel 3.

Pendidikan merupakan suatu proses jenjang pembelajaran umum yang dilakukan oleh suatu instansi. Arikunto (2012) membagi tingkat pendidikan ke dalam 2 kelompok yakni pendidikan rendah (Tidak Sekolah, SD, SMP) dan Pendidikan Tinggi (SMA, Universitas) yang mana dapat memengaruhi pola pikir serta kemampuan seorang individu menyerap teknologi baru yang ada. Hal ini didukung oleh penjabaran Soekartawi (1988) bahwa mereka yang memiliki jenjang lebih tinggi cenderung lebih dapat menerima suatu inovasi dibandingkan dengan yang berpendidikan lebih rendah. Hasil penelitian di lapangan ditemukan pendidikan rendah sebesar $77 \%$ atau sebanyak 23 orang dan petani pendidikan tinggi sebesar $33 \%$ atau sebanyak 7 orang dari populasi yang ada yang membuat anggota KWT Bijeh Mata mayoritas sebagai petani dengan pendidikan rendah.

Pengalaman usahatani merupakan lamanya seseorang mengusahakan suatu usaha pertanian yang mana dapat mempengaruhi keterampilan seseorang dalam menjalankan usaha tani. 
Tabel 3. Karakteristik Petani Responden

\begin{tabular}{|c|c|c|c|}
\hline No & Variabel & Skor & $\%$ \\
\hline \multirow{6}{*}{1} & Umur & & \\
\hline & a. 0-15 Tahun & 0 & 0 \\
\hline & b. 16-30 Tahun & 0 & 0 \\
\hline & c. 31-45 Tahun & 29 & 96,6 \\
\hline & d. 46-64 Tahun & 1 & 3,4 \\
\hline & e. 65 Keatas & 0 & 0 \\
\hline \multirow{6}{*}{2} & Pendidikan & & \\
\hline & a. Tidak Sekolah & 0 & 0 \\
\hline & b. SD & 19 & 63,33 \\
\hline & c. SMP & 4 & 13,33 \\
\hline & d. SMA & 7 & 23,33 \\
\hline & e. Sarjana & 0 & 0 \\
\hline \multirow{5}{*}{3} & Pengalaman Usahatani & & \\
\hline & a. 0-5 Tahun & 0 & 0 \\
\hline & b. 6-10 Tahun & 2 & 6,66 \\
\hline & c. 11-15 Tahun & 4 & 13,3 \\
\hline & d. $16>$ Tahun & 12 & 80,1 \\
\hline \multirow{4}{*}{4} & Luas Lahan & & \\
\hline & a. Lahan Sempit <0,5 Ha) & 0 & 0 \\
\hline & b. Lahan Sedang (0,5- $2 \mathrm{Ha})$ & 30 & 100 \\
\hline & c. Lahan Luas ( > $2 \mathrm{Ha})$ & 0 & 0 \\
\hline \multirow{3}{*}{5} & Status Kepemilikan Lahan & & \\
\hline & a. Pemilik & 19 & 63,33 \\
\hline & b. Penggarap & 11 & 36,67 \\
\hline \multirow{4}{*}{6} & Komunikasi & & \\
\hline & a. 1 - 2 Kali & 4 & 13,33 \\
\hline & b. 3 - 4 Kali & 13 & 43,33 \\
\hline & c. 5 Kali & 13 & 43,33 \\
\hline \multirow{5}{*}{7} & Pendapatan & & \\
\hline & a. Rp 0 - Rp 1.500 .000 & 3 & 10 \\
\hline & b. Rp $1.500 .000-R p 2.500 .000$ & 16 & 53,33 \\
\hline & c. Rp 2.500 .000 - Rp 3.500 .000 & 8 & 26,66 \\
\hline & d. > Rp 3.500.000 & 3 & 10 \\
\hline \multirow{4}{*}{8} & Intensitas Mengikuti Pelatihan & & \\
\hline & a. 1-3 Kali & 3 & 10 \\
\hline & b. 4 - 6 Kali & 16 & 53,33 \\
\hline & c. $>7$ Kali & 8 & 26,66 \\
\hline
\end{tabular}

Sumber: Data primer diolah, 2018

Orang dengan pengalaman usaha tani yang lebih lama akan cenderung lebih terampil jika dibandingkan dengan orang yang masih baru dalam usaha tani (Harianti, 2014). Menurut Soeharjo dan Patong (1999), ada tiga kategori pengalaman usahatani yaitu kurang berpengalaman $\quad(<5 \quad$ tahun $), \quad$ cukup berpengalaman (5-10 tahun), dan berpengalaman (>10 tahun). Dari hasil peneliitian ditemukan dimana seluruh populasi dari Kelompok Wanita Tani (KWT) Bijeh Mata digolongkan sebagai petani cukup berpengalaman sebanya 2 orang atau sebesar $6,66 \%$ dan selebihnya digolongkan sebagai petani yang berpengalaman dengan pengalaman di atas 10 tahun dikarenakan dalam mengusahakan komoditi padi sudah dilakukan sejak usia muda yang turun temurun dilakukan dari orang tua dan dilanjutkan ke generasi selanjutnya.

Luas lahan merupakan luas keseluruhan areal yang digunakan dalam usaha tani yang mana hal ini memiliki kontribusi dalam mempengaruhi petani untuk menerapkan suatu inovasi yang memungkinkan dalam usaha tani yang ada. Hernanto (1993), membagi luas lahan menjadi beberapa kategori: 1) Lahan luas (>2 hektar); 2) Lahan sedang (0,5-2 hektar); 3) Lahan sempit $(<0,5$ hektar). Dari Tabel 3 disimpulkan bahwa anggota Kelompok Wanita Tani (KWT) Bijeh Mata seluruhnya termasuk memiliki luas lahan sedang yakni antara $0,5 \mathrm{Ha}$ sampai 2 Ha. Status kepemilikan lahan merupakan suatu pengakuan secara hukum tentang kepemilikan dari lahan pertanian yang diusahakan yang mana petani dalam hal ini dibagi kedalam dua kelompok yakni petani penggarap dan petani pemilik.

Menurut Soekartawi (1988) petani yang juga berperan sebagai pemilik lahan memiliki kekuasaan atau kebebasan dalam menerapkan atau mengadopsi teknologi tanpa ada campur tangan oleh pihak lain yang dibandingkan petani penggarap yang mempertimbangkan keputusan pemilik lahan yang menjalin kerjasama. Hasil penelitian di lapangan petani penggarap sebesar $37 \%$ atau sebanyak 11 orang dan petani yang memiliki lahan pribadi sebesar 63\% atau sebanyak 19 orang. Dari jumlah di atas dapat disimpulkan jumlah petani yang memiliki lahan pertanian secara pribadi lebih banyak atau menjadi mayoritas jika dibandingkan dengan petani yang tidak mempunyai lahan atau dengan nama lain petani penggarap. Komunikasi merupakan hubungan dan interaksi yang dilakukan petani sehingga menimbulkan aksi dan reaksi antara satu sama lain yang juga akan mempengaruhi seseorang untuk mengadopsi suatu inovasi. Hasil penelitian petani dengan jumlah komunikasi 12 kali dalam sebulan sebesar 13\%, Komunikasi 3-4 kali per bulan sebesar $44 \%$ dan petani dengan jumlah komunikasi di atas 5 kali per bulan $43 \%$ yang mana dapat disimpulkan bahwa tingkat komunikasi yang dilakukan oleh anggota KWT mayoritas 3-5 kali per bulan.

Hasil survei di lapangan, jumlah pendapatan terendah $\mathrm{Rp} 1.500 .000$ kebawah sebesar $10 \%$ dan pendapatan tertinggi petani dengan jumlah 3 orang yang memiliki pendapatan di atas Rp 3.500.000 adalah sebesar 
10\%. Berdasarkan Tabel 3 di atas dapat disimpulkan bahwa pendapatan kebanyakan anggota KWT diisi oleh golongan berpendapatan Rp 1.500.000 - Rp 2.500.000 sebanyak $53,33 \%$ dan selebihnya pendapatan yang sedang dan tinggi. Intensitas yang dimaksud adalah banyaknya petani menghadiri atau mengikuti pelatihan atau penyuluhan yang dilakukan oleh penyuluh. Tabel 3 dapat dilihat petani dengan jumlah komunikasi jarang sebesar 30\%, komunikasi sedang 57\% dan petani dengan jumlah komunikasi tinggi $13 \%$. Berdasarkan jumlah di atas dapat disimpulkan sebagian besar anggota KWT Bijeh Mata memiliki intensitas komunikasi antar petani tergolong sedang.

\section{Tingkat Persepsi Petani Terhadap Penerapan Metode SRI}

Persepsi petani terhadap metode SRI dilakukan dengan memberikan pertanyaan yang menggambarkan persepsi petani. Setelah melakukan penelitian kepada anggota KWT Bijeh Mata terhadap metode budidaya SRI diperoleh data sebagai berikut:

\section{Keuntungan Relatif}

Menyatakan persepsi dimana inovasi yang baru dapat meningkatkan keuntungan dari pada metode yang telah diterapkan sebelumnya, pada penelitian ini keuntungan relatif yang dilihat melalui 3 dimensi yaitu a) Menghemat biaya adalah persepsi terhadap inovasi dapat meningkatkan keuntungan dengan penurunan biaya produksi dalam budidaya. Hasil penelitin menunjukkan tingkat persepsi bernilai 3,8 menggambarkan bahwa metode SRI memberikan keuntungan ekonomi dalam menurunkan biaya produksi dibandingkan dengan metode konvensional yang diterapkan sebelumnya. b) Efesiensi waktu adalah persepsi terhadap inovasi dapat meningkatkan keuntungan dengan mengurangi waktu yang digunakan dalam proses budidaya. Hasil penelitian juga menemukakan bahwa tingkat persepsi bernilai 2,4 yang artinya nilai tersebut menggambarkan bahwa metode SRI jarang memberikan keuntungan dalam mengurangi waktu dalam budidaya. c) Peningkatan pendapatan adalah persepsi terhadap inovasi dapat meningkatkan keuntungan dengan meningkatkan harga jual gabah yang dihasilkan.

\section{Tingkat Kesesuaian}

Dalam penelitian ini melihat tingkat kesesuaian melalui 3 dimensi yakni a) Kondisi lingkungan adalah persepsi terhadap inovasi dapat dilakukan dengan kondisi lingkungan tempat petani berada. Hasil penelitian menujukkan tingkat persepsi bernilai 3,6 yang menggambarkan bahwa metode SRI dapat dilakukan dan sesuai dengan keadaan lingkungan yang ada. b) Kebiasaan adalah persepsi terhadap inovasi dapat menggantikan metode konvensional yang telah menjadi kebiasaan yang telah ada. Hasil penelitian menunjukkan bahwa metode SRI sedikit dapat menggantikan metode konvensional yang telah menjadi kebiasaan yang telah dilakukan. c) Kebutuhan adalah persepsi terhadap inovasi sesuai dengan kebutuhan yang dirasakan oleh petani. Berdasarkan hasil penelitian menunjukkan bahwa metode SRI sedikit memenuhi kebutuhan petani.

\section{Tingkat Kerumitan}

Tingkat kerumitan dapat dilihat melalui 3 dimensi yaitu: a) Kemudahan adalah persepsi terhadap inovasi dapat dilakukan dengan mudah oleh petani. Hasil penelitian menunjukkan bahwa metode SRI dapat dilakukan dan sesuai dengan keadaan lingkungan yang ada. b) Kepraktisan adalah persepsi terhadap inovasi dapat di praktekkan dengan praktis dan tidak merepotkan petani. Tingkat persepsi bernilai 2,6 yang artinya nilai tersebut menggambarkan bahwa metode SRI dapat sedikit atau jarang memenuhi segi kepraktisan saat digunakan oleh petani. c) Keterampilan adalah persepsi terhadap inovasi sesuai dengan pengaplikasian teknologi tidak membutuhkan suatu keterampilan khusus yang di pelajari untuk menggunakannya. Tingkat persepsi bernilai 4,6 yang berarti nilai tersebut menggambarkan bahwa metode SRI sama sekali tidak memerlukan keterampilan khusus untuk dipelajari dalam menggunakannya.

\section{Kemampuan Diuji}

Penelitian kemampuan diuji ini dilihat melalui 3 dimensi yaitu: a) Skala lahan adalah persepsi terhadap inovasi dapat dilakukan dengan luas lahan yang dimiliki oleh petani, tingkat persepsi bernilai 4,5 yang mana nilai tersebut menggambarkan bahwa metode SRI dapat dilakukan dengan keadaan luas lahan yang 
dimiliki. b) Keadaan alam lahan adalah persepsi terhadap inovasi dapat dengan letak kondisi dan keadaan alam yang dimiliki oleh petani yang telah ada, tingkat persepsi bernilai 3,9 yang menggambarkan bahwa metode SRI dapat dilakukan mengikuti keadaan alam dari lahan petani yang sudah ada. c) Pengaplikasian pada demplot percobaan adalah persepsi terhadap inovasi berhasil diuji coba dalam demplot, tingkat persepsi bernilai 4,3 dimana nilai tersebut menggambarkan bahwa metode SRI telah berhasil diuji coba pada demplot percobaan.

\section{Kemudahan untuk Dilihat Hasilnya}

Kemudahan untuk dilihat hasilnya dibagi melalui 3 dimensi yaitu: a) Tampak fisik tanaman adalah persepsi terhadap inovasi dapat memperlihatkan perubahan fisik yang signifikan pada tampilan fisik tanaman, tingkat persepsi bernilai 4,3 yang mana nilai tersebut menggambarkan bahwa metode SRI memperlihatkan perbedaan perubahan tampakkan fisik tanaman dari metode konvensional. b) Mutu produksi adalah persepsi terhadap inovasi dapat meningkatkan mutu gabah yang dihasilkan, tingkat persepsi bernilai 2,6 yang berarti bahwa metode SRI sedikit atau jarang meningkatkan mutu dari gabah hasil produksi. c) Peningkatan produksi adalah persepsi terhadap inovasi dapat meningkatkan produksi hasil dari tanaman. tingkat persepsi bernilai 4,5 yang mana nilai tersebut menggambarkan bahwa metode SRI dapat meningkatkan jumlah hasil produksi gabah.

Secara keseluruhan rata rata persepsi petani anggota KWT Bijeh Mata dilakukan memiliki nilai 3,3 dengan menggunakan skala pengukuran likert menunjukkan bahwa tingkat persepsi masih dikatagorikan baik. Sebaran data persepsi petani terhadap penerapan metode SRI secara lengkap disajikan pada Tabel 4.

\section{Hubungan antara Persepsi Dengan Karakteristik Petani}

Hasil uji analisis korelasi rank spearman untuk menganalisis hubungan antara persepsi petani terhadap metode budidaya SRI dengan karakteristik petani responden mendapatkan hasil sebagai berikut, untuk data hasil keseluruhan dapat dilihat pada Tabel 5.

\section{Keuntungan Relatif}

Menyatakan persepsi dimana inovasi yang baru dapat meningkatkan keuntungan daripada metode yang telah diterapkan sebelumnya. Pada penelitian ini keuntungan relatif yang dilihat melalui 3 dimensi yaitu: a) Menghemat biaya adalah persepsi terhadap inovasi dapat meningkatkan keuntungan dengan penurunan biaya produksi dalam budidaya.

Tabel 4. Sebaran Data Persepsi Petani Terhadap Penerapan Metode SRI

\begin{tabular}{|c|c|c|c|c|c|c|c|c|}
\hline No. & Indikator & Dimensi & $\begin{array}{l}\text { SS } \\
(5)\end{array}$ & $\begin{array}{l}S \\
(4)\end{array}$ & $\begin{array}{l}\mathrm{N} \\
(3)\end{array}$ & $\begin{array}{l}\text { TS } \\
(2)\end{array}$ & $\begin{array}{l}\text { STS } \\
(1)\end{array}$ & $\begin{array}{l}\text { Tingkat } \\
\text { Persepsi }\end{array}$ \\
\hline \multirow[t]{4}{*}{1} & Keunggulan Relatif & Menghemat Biaya & - & 25 & 5 & - & - & 3,8 \\
\hline & & Efesiensi Waktu & - & - & 14 & 16 & - & 2,4 \\
\hline & & Peningkatan & - & - & - & 30 & - & 2 \\
\hline & & Pendapatan & & & & & & \\
\hline \multirow[t]{3}{*}{2} & Tingkat Kesesuaian & Kondisi Lingkungan & - & 19 & 11 & - & - & 3,6 \\
\hline & & Kebiasaan & - & - & 17 & 13 & - & 2,8 \\
\hline & & Kebutuhan & & & 12 & 18 & - & 2,4 \\
\hline \multirow[t]{3}{*}{3} & Tingkat Kerumitan & Kemudahan & - & - & 19 & 11 & - & 2,6 \\
\hline & & Kepraktisan & - & - & 19 & 11 & - & 2,6 \\
\hline & & Keterampilan & 19 & 11 & - & - & - & 4,6 \\
\hline \multirow[t]{3}{*}{4} & Kemampuan di Uji & Skala Lahan & 15 & 15 & - & - & - & 4,5 \\
\hline & & Keadaan Alam Lahan & 8 & 11 & 11 & - & - & 3,9 \\
\hline & & Demplot Percobaan & 11 & 19 & - & - & - & 4,3 \\
\hline \multirow[t]{5}{*}{5} & Kemudahan Dilihat & Tampak Fisik & 11 & 19 & - & - & - & 4,3 \\
\hline & Hasil & Tanaman & & & & & & \\
\hline & & Mutu produksi & - & - & 19 & 11 & - & 2,6 \\
\hline & & Peningkatan Produksi & 15 & 15 & - & - & - & 4,5 \\
\hline & & & & & & & & 3,3 \\
\hline
\end{tabular}

Sumber: Data primer diolah, 2018 
Tabel 4 menyajikan bahwa tingkat persepsi bernilai 3,8 yang mana nilai tersebut menggambarkan bahwa metode SRI memberikan keuntungan ekonomi dalam menurunkan biaya produksi dibandingkan dengan metode konvensional yang diterapkan sebelumnya. b) Efesiensi waktu adalah persepsi terhadap inovasi dapat meningkatkan keuntungan dengan mengurangi waktu yang digunakan dalam proses budidaya. Berdasarkan Tabel 4 dapat dilihat bahwa tingkat persepsi bernilai 2,4 yang artinya metode SRI jarang memberikan keuntungan dalam mengurangi waktu dalam budidaya. c) Peningkatan pendapatan adalah persepsi terhadap inovasi dapat meningkatkan keuntungan dengan meningkatkan harga jual gabah yang dihasilkan. Tabel 4 menunjukkan bahwa tingkat persepsi bernilai 2 yang mana nilai tersebut menggambarkan bahwa metode SRI jarang memberikan keuntungan dalam meningkatkan harga jual gabah yang dihasilkan, tetapi sama dengan metode konvensional.

\section{Tingkat Kesesuaian}

Menyatakan persepsi dimana inovasi yang baru sesuai untuk dapat dilakukan sesuai keadaan tempat penelitian, pada penelitian ini tingkat kesesuaian yang dilihat melalui 3 dimensi yakni a) Kondisi lingkungan adalah persepsi terhadap inovasi dapat dilakukan dengan kondisi lingkungan tepat petani berada, berdasarkan Tabel 4 dapat dilihat bahwa tingkat persepsi bernilai 3,6 yang mana nilai tersebut menggambarkan bahwa metode SRI dapat dilakukan dan sesuai dengan keadaan lingkungan yang ada. b) Kebiasaan adalah persepsi terhadap inovasi dapat menggantikan metode konvensional yang telah menjadi kebiasaan yang telah ada, berdasarkan tabel diatas dapat dilihat bahwa tingkat persepsi bernilai 2,8 yang mana nilai tersebut menggambarkan bahwa metode SRI dapat sedikit dapat menggantikan metode konvensional yang telah menjadi kebiasaan yang telah dilakukan. c) Kebutuhan adalah persepsi terhadap inovasi sesuai dengan kebutuhan yang dirasakan oleh petani. Tabel 4 menunjukkan bahwa tingkat persepsi bernilai 2,4 yang mana nilai tersebut menggambarkan bahwa metode SRI sedikit memenuhi kebutuhan petani.

\section{Tingkat Kerumitan}

Menyatakan persepsi dimana inovasi yang baru sesuai untuk dapat dilakukan sesuai keadaan tempat penelitian, pada penelitian ini tingkat kesesuaian yang dilihat melalui 3 dimensi yakni a) Kemudahan adalah persepsi terhadap inovasi dapat dilakukan dengan mudah oleh petani, berdasarkan Tabel 4 dapat dilihat bahwa tingkat persepsi bernilai 3,6 yang mana nilai tersebut menggambarkan bahwa metode SRI dapat dilakukan dan sesuai dengan keadaan lingkungan yang ada. b) Kepraktisan adalah persepsi terhadap inovasi dapat di praktekkan dengan praktis dan tidak merepotkan petani, berdasarkan tabel diatas dapat dilihat bahwa tingkat persepsi bernilai 2,6 yang mana nilai tersebut menggambarkan bahwa metode SRI dapat sedikit atau jarang memenuhi segi kepraktisan saat digunakan oleh petani. c) Keterampilan adalah persepsi terhadap inovasi sesuai dengan pengaplikasian teknologi tidak membutuhkan suatu keterampilan khusus yang di pelajari untuk menggunakannya. Tabel 4 menunjukkan bahwa tingkat persepsi bernilai 4,6 yang mana nilai tersebut menggambarkan bahwa metode SRI sama sekali tidak memerlukan keterampilan khusus untuk di pelajari dala menggunakannya.

\section{Kemampuan Diuji}

Menyatakan persepsi dimana inovasi yang baru sesuai untuk dapat dilakukan sesuai keadaan tempat penelitian, pada penelitian ini tingkat kesesuaian yang dilihat melalui 3 dimensi yakni a) Skala lahan adalah persepsi terhadap inovasi dapat dilakukan dengan luas lahan yang dimiliki oleh petani, berdasarkan Tabel 4 dapat diketahui bahwa tingkat persepsi bernilai 4,5 yang mana nilai tersebut menggambarkan bahwa metode SRI dapat dilakukan dengan keadaan luas lahan yang dimiliki. b) Keadaan alam lahan adalah persepsi terhadap inovasi dapat dengan letak kondisi dan keadaan alam yang dimiliki oleh petani yang telah ada, berdasarkan Tabel 4 dapat diketahui bahwa tingkat persepsi bernilai 3,9 yang mana nilai tersebut menggambarkan bahwa metode SRI dapat dilakukan mengikuti keadaa alam dari lehan petani yang sudah ada. c) Pengaplikasian pada demplot percobaan adalah persepsi terhadap inovasi berasil di uji coba dalam demplot. Tabel 4 menunjukkan bahwa tingkat persepsi bernilai 4,3 yang mana nilai tersebut 
menggambarkan bahwa metode SRI telah berhasil di uji coba pada demplot pecobaan.

\section{Kemudahan Untuk Dilihat Hasilnya}

Menyatakan persepsi dimana inovasi yang baru sesuai untuk dapat dilakukan sesuai keadaan tempat penelitian, pada penelitian ini tingkat kesesuaian yang dilihat melalui 3 dimensi yakni a) Tampak fisik tanaman adalah persepsi terhadap inovasi dapat memperlihatkan perubahan fisik yang signifikan pada tampilan fisik tanaman. Tabel 4 menggambarkan bahwa tingkat persepsi bernilai 4,3 yang mana nilai tersebut menggambarkan bahwa metode SRI memperlihatkan perbedaan perubahan tampakkan fisik tanaman dari metode konvensional. b) Mutu produksi adalah persepsi terhadap inovasi dapat meningkatkan mutu gabah yang dihasilkan, berdasarkan tabel diatas, diketahui bahwa tingkat persepsi bernilai 2,6 yang mana nilai tersebut menggambarkan bahwa metode SRI sedikit atau jarang meningkatkan mutu dari gabah hasil produksi. c) Produksi adalah persepsi terhadap inovasi dapat meningkatkan produksi hasil dari tanaman. Berdasarkan tabel diatas dapat dilihat bahwa tingkat persepsi bernilai 4,5 yang mana nilai tersebut menggambarkan bahwa metode SRI dapat meningkatkan jumlah hasil produksi gabah.

Secara keseluruhan rata rata persepsi petani anggota KWT Bijeh Mata dilakukan memiliki nilai 3,3 dengan menggunakan skala pengukuran likert menunjukkan bahwa tingkat persepsi masih dikatagorikan baik dan menjawab hipotesis terima $\mathrm{HO}$ tolak Ha.

Tabel 5. Korelasi Karakteristik dan Persepsi Terhadap Metode SRI

\begin{tabular}{lllr}
\hline Analisis & Karakteristik & & Persepsi \\
\hline Spearman's rho & Luas_lahan & Correlation Coefficient &, 222 \\
& & Sig. (2-tailed) &, 237 \\
& Umur & Correlation Coefficient & 30 \\
& & Sig. (2-tailed) &, $433^{*}$ \\
& Pengalaman & Correlation Coefficient &, 017 \\
& Sig. (2-tailed) & 30 \\
& N &, 334 \\
& Pendapatan & Correlation Coefficient &, 071 \\
& & Sig. (2-tailed) & 30 \\
& Kepemilikan & Correlation Coefficient &, 206 \\
& Sig. (2-tailed) &, 275 \\
& N & 30 \\
& Pendidikan & Correlation Coefficient &, $384^{*}$ \\
& Sig. (2-tailed) &, 036 \\
& N & 30 \\
& Jlh_Pelatihan & Correlation Coefficient &, 338 \\
& Sig. (2-tailed) &, 068 \\
& N & 30 \\
& Jlh_Komunikasi & Correlation Coefficient &, 274 \\
& Sig. (2-tailed) &, 142 \\
& N & 30 \\
& Correlation Coefficient &, $398^{*}$ \\
& Sig. (2-tailed) &, 029 \\
& N & 30 \\
& & 1,000 \\
& & 30 \\
\hline
\end{tabular}

Sumber: Data primer diolah, 2018 
a. Umur

Hasil uji korelasi yang telah dilakukan menunjukkan bahwa umur dari petani mempunyai hubungan dengan persepsi yang di tunjukkan dengan nilai sig 0,017 yang lebih kecil dari 0,05 dan mempunyai keeratan yang kuat ditunjukkan oleh nilai korelasi sebesar 0,433 . Hal ini menunjukkan bahwa semakin bertambahnya umur petani dalam usia produktif akan meningkatkan kemampuan petani untuk menerima informasi dan masukan yang baru ke dalam sistem pertaniannya. Hal ini berbanding terbalik dengan pernyataan Soekartawi (2005) makin muda usia petani petani biasanya petani mempunyai semangat dan rasa ingin tahu yang besar, sehingga mereka lebih cepat untuk melakukan adopsi inovasi.

\section{b. Pendidikan}

Hasil uji korelasi yang telah dilakukan menunjukkan bahwa pendidikan dari petani tidak mempunyai hubungan dengan persepsi yang di tunjukkan dengan nilai sig 0,068 yang lebih besar dari 0,05. Pendidikan formal tidak menjadi acuan dalam diri petani responden untuk dapat menerima informasi dan masukan yang baru dalam sistem pertaniannya. Hasil ini berbanding terbalik dengan pernyataan Sumarwan (2003) mengatakan bahwa tingkat pendidikan menentukan perilaku seseorang dalam menerima pengetahuan dan informasi. Petani berpendidikan tinggi relatif lebih cepat dalam melaksanakan adopsi.

\section{c. Luas Lahan}

Hasil uji korelasi yang telah dilakukan menunjukkan bahwa luas lahan dari petani tidak mempunyai hubungan dengan persepsi, ditunjukkan dengan nilai sig 0,237 yang lebih besar dari 0,05 . Luas lahan yang dimiliki oleh petani tidak menjadi alasan atau acuan dalam diri petani dalam menerima informasi dan masukan yang baru dalam sistem pertaniannya. Hasil ini diakibatkan petani akan mencoba suatu hal yang baru di lahan yang kecil untuk percoban sebelum mengaplikasikannya ke lahan pertanian yang lebih luas. Sejalan dengan pendapat Romli (2016) bahwa suatu inovasi yang dapat diujicobakan dalam keadaan sesungguhnya dan mampu menunjukkan keunggulannya maka adopsi inovasi yang dilakukan petani juga akan lebih cepat.

\section{d. Status Kepemilikan Lahan}

Hasil uji korelasi yang telah dilakukan menunjukkan bahwa status kepemilikan lahan dari petani mempunyai hubungan dengan persepsi yang di tunjukkan dengan nilai sig 0,036 yang lebih kecil dari 0,05 dan mempunyai keeratan yang cukup kuat ditunjukkan oleh nilai korelasi sebesar 0,384. Petani yang memiliki sendiri lahan pertaniannya dinilai lebih dapat menerima informasi dan masukan dalam sistem pertaniannya kerena petani yang memiliki lahan pribadi juga memiliki kebebasan baik dalam menentukan metode yang mreka gunakan tanpa mempertimbangkan pendapat dan kekhawatiran pemilik lahan dari pada petani yang hanya menggarap lahan pertanian orang lain. Hasil ini selaras dengan pernyataan Sutarto (2008) mengatakan kepemilikan dan luas lahan berhubungan dengan tingkat adopsi inovasi petani.

\section{e. Komunikasi}

Hasil uji korelasi yang telah dilakukan menunjukkan bahwa komunikasi antar petani dari responden mempunyai hubungan dengan persepsi yang ditunjukkan dengan nilai sig 0,029 yang lebih kecil dari 0,05 dan mempunyai keeratan yang cukup kuat di tunjukkan oleh nilai korelasi sebesar 0,398. Hal ini menunjukkan bahwa petani yang lebih sering berkomunikasi dengan petani lain untuk mendiskusikan masalah pertanian memiliki kemampuan untuk lebih menerima informasi dan masukan baru ke dalam sistem pertaniannya dibandingkan dengan yang jarang melakukan komunikasi. Hasil ini selaras dengan pernyataan Rogers dalam Fuady (2012) seseorang akan lebih cepat mengadopsi inovasi, apabila ia lebih banyak melakukan kontak komunikasi interpersonal dengan agen pembaharu dan tokoh masyarakat.

\section{f. Pendapatan}

Hasil uji korelasi yang telah dilakukan menunjukkan bahwa pendapatan yang diperoleh petani tidak mempunyai hubungan dengan persepsi yang di tunjukkan dengan nilai sig 0,275 yang lebih besar dari 0,05. Pendapatan yang dimiliki oleh petani tidak menjadi alasan atau acuan dalam diri petani untuk lebih mudah dalam menerima informasi dan masukan yang baru dalam sistem 
pertaniannya. Hasil ini berbanding terbalik dengan penelitian yang dilakukan (Utomo, 2012) yang menyatakan bahwa semakin tinggi pendapatan petani akan mendapatkan persepsi yang semakin baik.

\section{g. Intensitas Mengikuti Pelatihan}

Hasil uji korelasi yang telah dilakukan menunjukkan bahwa intensitas mengikuti pelatihan yang diperoleh petani tidak mempunyai hubungan dengan persepsi, ditunjukkan dengan nilai sig 0,142 yang lebih besar dari 0,05 . Petani yang lebih banyak mengikuti pelatihan tidak menjadi acuan dalam diri petani untuk lebih mudah dalam menerima informasi dan masukan yang baru dalam sistem pertaniannya. Hasil ini berbanding terbalik dengan penelitian oleh (Radhakrishna, 2010) yang menjelaskan bahwa melalui pelatihan dan pemberdayaan akan tercipta perubahan pengetahuan, opini, aspirasi dan keterampilan yang akan membuat persepsi yang lebih baik pada suatu informasi.

\section{h. Pengalaman}

Hasil uji korelasi yang telah dilakukan menunjukkan bahwa umur dari petani mempunyai hubungan dengan persepsi, di tunjukkan dengan nilai sig 0,071 yang lebih besar dari 0,05. Petani yang lebih banyak memiliki pengalaman lebih lama tidak menjadi acuan dalam diri petani untuk lebih mudah dalam menerima informasi dan masukan yang baru dalam sistem pertaniannya. Hasil ini berbanding terbalik dengan penelitian yang dilakukan oleh (Hasyim, 2003) yang menyatakan bahwa petani yang sudah lama berusaha tani akan lebih mudah menerapkan anjuran penyuluh demikian pula dengan penerapan teknologi. Lamanya berusahatani untuk setiap orang berbeda-beda oleh karena itu lamanya berusahatani dapat dijadikan bahan pertimbangan agar tidak melakukan kesalahan yang sama sehingga dapat melakukan hal-hal baik untuk waktu berikutnya.

Dari uraian di atas maka dilakukan keputusan terima $\mathrm{Ha}$ dan tolak $\mathrm{H} 0$ yang menjelaskan bahwa adanya hubungan antara karakteristik petani responden terhadap persepsi mereka tentang metode budidaya SRI pada karakteristik umur keeratan yang kuat serta kepemilikan dan komunikasi antar petani dengan keeratan yang cukup kuat. Dari uraian keputusan terima $\mathrm{H} 0$ dan tolak $\mathrm{Ha}$ yang menjelaskan bahwa tidak adanya hubungan antara karakteristik pendapatan, luas lahan, intensitas pelatihan dan pendidikan formal.

\section{KESIMPULAN DAN SARAN}

Secara keseluruhan, rata-rata persepsi petani anggota KWT Bijeh Mata memiliki nilai 3,3 yang diukur dengan menggunakan skala pengukuran likert. Hal ini menunjukkan bahwa tingkat persepsi masih dikatagorikan baik dan menjawab hipotesis terima $\mathrm{HO}$ tolak $\mathrm{Ha}$. Adanya hubungan antara karakteristik umur dengan persepsi petani dengan dengan nilai sig 0,017 yang lebih kecil dari 0,05 dan mempunyai keeratan yang kuat di tunjukkan oleh nilai korelasi sebesar 0,433. Hubungan pada karakteristik status kepemilikan dengan persepsi cukup kuat, ditunjukkan dengan nilai sig 0,036 yang lebih kecil dari 0,05 serta mempunyai keeratan yang cukup kuat di tunjukkan oleh nilai korelasi sebesar 0,384. Komunikasi antar petani dengan persepsi memiliki nilai sig 0,029 yang lebih kecil dari 0,05 dan mempunyai keeratan yang cukup kuat di tunjukkan oleh nilai korelasi sebesar 0,398. Karakteristik pendapatan, luas lahan, pendidikan, pengalaman serta intensitas mengikuti pelatihan pertanian di sisi lain tidak memiliki hubungan dengan persepsi petani terhadap metode budidaya SRI ditunjukkan dengan nilai sig yang lebih besar dari 0,05.

\section{DAFTAR PUSTAKA}

Arikunto, S. 2012. Prosedur Penelitian suatu Pendekatan Praktik. Jakarta: PT Rineka Cipta.

Badan Pusat Statistik Kabupaten Aceh Besar. 2017. Kabupaten Aceh Besar dalam Angka. Aceh Besar: BPS Kabupaten Aceh Besar.

Hasyim, H. 2003. Analisis Hubungan Faktor Sosial, Ekonomi Petani terhadap Program Penyuluhan Pertanian. Laporan Hasil Penelitian. Medan: Universitas Sumatera Utara.

Hernanto. 1993. Ilmu Usahatani. Jakarta: Penebar Swadaya. 
Kurniadiningsih, Y., dan Legowo, S. 2012. Evaluasi Untung Rugi Penerapan Metode SRI (System of Rice Intensification) di D.I. Cihea Kabupaten Cianjur Jawa Barat. Wartazoa, 18 (7), 97 - 105.

Siegel, S. 1992. Statistika Nonparametrik. Jakarta: PT Gramedia Pustaka Utama.

Soeharjo, A., dan Patong, F. 1999. Sendi-sendi Pokok Ilmu Usahatani. Departemen Ilmu-Ilmu Sosial Ekonomi. Bogor: Institut Pertanian Bogor.

Soekartawi. 1988. Prinsip Dasar Komunikasi Pertanian. Jakarta: Universitas Indonesia Press.

Soekartawi. 2005. Agroindustri dalam Perspektif Sosial Ekonomi. Jakarta: Raja Grafindo Persada.
Sumarwan, U. 2003. Perilaku Konsumen, Teori dan Penerapannya dalam Pemasaran. Jakarta: Ghalia Indonesia.

Sutarto. 2008. Hubungan Sosial Ekonomi Petani dengan Tingkat Adopsi Inovasi Teknologi Komoditas Jagung di Sidoharjo Wonogiri. Agritex, 24 (1), 1 12.

Tuwo, A. 2011. Pengelolaan Ekowisata Pesisir dan Laut. Surabaya: Brilian Internasional.

Utomo, P. 2012. Presepsi Petani terhadap Metode Budidaya Padi System of Rice Intensification (SRI) di Desa Ringgit Kecamatan Ngombol Kabupaten Purworejo. Skripsi. Program Studi Agribisnis. Fakultas Pertanian. Universitas Muhammadiyah Purworejo, Purworejo. 